A NEW BANKRUPTCY PROCEDURE THAT USES MULTIPLE AUCTIONS

\author{
Oliver Hart \\ Rafael La Porta Drago \\ Florencio Lopez-de-Silanes \\ John Moore
}

Working Paper 6278 
NBER WORKING PAPER SERIES

\title{
A NEW BANKRUPTCY PROCEDURE THAT USES MULTIPLE AUCTIONS
}

\author{
Oliver Hart \\ Rafael La Porta Drago \\ Florencio Lopez-de-Silanes \\ John Moore
}

Working Paper 6278

http://www.nber.org/papers/w6278

\section{NATIONAL BUREAU OF ECONOMIC RESEARCH 1050 Massachusetts Avenue \\ Cambridge, MA 02138 \\ November 1997}

We are grateful for the comments of Lemma Senbet, Andrei Shleifer, and participants at the conference on The Future of Emerging-Market Capital Flows (New York University, May 1996) and at the Eleventh Annual Congress of the European Economic Association (Istanbul, August 1996). We also thank Fernando Salas for helpful conversations. This work has been supported by a grant from the National Science Foundation to the National Bureau of Economic Research. Any opinions expressed are those of the authors and not those of the National Bureau of Economic Research.

(C) 1997 by Oliver Hart, Rafael La Porta Drago, Florencio Lopez-de-Silanes and John Moore. All rights reserved. Short sections of text, not to exceed two paragraphs, may be quoted without explicit permission provided that full credit, including $\mathbb{C}$ notice, is given to the source. 
A New Bankruptcy Procedure that Uses

Multiple Auctions

Oliver Hart, Rafael La Porta Drago,

Florencio Lopez-de-Silanes and John Moore

NBER Working Paper No. 6278

November 1997

JEL Nos. G33, K22

\section{$\underline{\text { ABSTRACT }}$}

We develop a new bankruptcy procedure that makes use of multiple auctions. The procedure is designed to work even when capital markets do not function well (for example in developing economies, or in economies in transition) -- although it can be used in all economies.

Oliver Hart

Department of Economics

Littauer Center 220

Harvard University

Cambridge, MA 02138

and NBER

oliver_hart@harvard.edu

Florencio Lopez-de-Silanes

Kennedy School of Government

Harvard University

79 JFK Street

Cambridge, MA 02138

and NBER

f_lopezdesilanes@harvard.edu
Rafael La Porta Drago

Department of Economics

Harvard University

Cambridge, MA 02138

John Moore

London School of Economics

Houghton Street

London WC2A $2 \mathrm{AE}$

UNITED KINGDOM 
We develop a new bankruptcy procedure, which is designed to work even when capital markets do not function well. The procedure is a significant development of that in Aghion, Hart and Moore (1992, 1995), and draws in part on our proposal to modify bankruptcy law in Mexico (Hart, La Porta Drago, Lopez-de-Silanes, Moore and Salas, 1995).

After a firm goes into bankruptcy, offers to reorganize the firm are solicited. An offer may comprise some combination of cash and non-cash securities; and so, in the absence of well-functioning capital markets, it cannot be evaluated objectively. There is therefore no clear-cut way of ranking offers. Any decision over the firm's future -- which offer to accept -- is further complicated by the fact that the people with claims against the firm (creditors and shareholders) have conflicting interests, depending on the seniority of their claims.

Our procedure avoids such conflicts by aligning people's interests: the various claims are transformed into one common security, Reorganization Rights (RRs). This transformation is achieved by means of two auctions. First, there is an inside auction, in which claimants can acquire RRs at prices which reflect the seniority of their respective claims. The point of holding the inside auction is to give claimants preferential rights to buy RRs. Next, there is a public auction, in which outside investors place cash bids to buy RRs from those claimants who acquired RRs in the earlier inside auction. Reserve prices in the public auction are set at levels high enough to stop outsiders from acquiring RRs too cheaply. The point of holding the public auction is, on the one hand, to provide an early opportunity for creditors to get repaid in cash; and, on the other hand, to generate surplus revenues which can be used to compensate those claimants who, because of liquidity constraints, were unable to participate in the earlier inside auction.

The procedure ends with a vote by the newly-assembled group of RR-holders to decide on which reorganization offer to accept. Note that not all firms will survive the procedure intact: of ten the winning "reorganization" offer will be a plan to wind up the business and dispose of the assets. 
In a way our procedure really consists of three auctions, since the solicitation of cash and non-cash offers for the bankrupt firm is itself an auction (over and above the inside and public auctions for RRs). This auction for the whole firm differs from the other two in an important way. The bidders are "active" agents with plans about the firm's future. In contrast, the bidders for RRs in the inside and public auctions are likely to be small investors who want to participate -- as passive agents -- in the firm's future (although in principle there is nothing to stop someone from trying to acquire a large number of RRs in the public auction with a view to becoming active later). Thus, as we shall argue, each auction has a useful, but separate, role to play.

Overall, our procedure aims to be efficient and to preserve absolute priority (i.e. to respect the seniority of claims). The procedure is also fast, cheap, decentralized and mechanical, leaving little discretionary power in the hands of courts, management or creditor/shareholder representatives. And because managers have to win the final vote in order to keep their jobs, the procedure maintains the bonding role of debt.

\section{Existing bankruptcy procedures}

We believe that in any bankruptcy, the choice of what to do with the firm's assets (efficiency) should ideally be divorced from the question of who gets what (distribution). This is particularly true in situations where capital markets cannot be relied on -- e.g. in developing economies, or in economies in transition (although we note that our new procedure is designed for use in all economies). Unfortunately, existing bankruptcy procedures fall well short of this ideal.

Many countries' bankruptcy law affords the opportunity for some form of structured bargaining (e.g. Chapter 11 in the U.S.), in which the firm's claimants attempt to reach agreement on both how to reorganize the firm and by how much each claim should be reduced. Typically, a plan is implemented if it receives approval by a suitable majority of each claimant class: unanimity is not required. (See, for example, the study by the American Bar Association, 1989 and 1993, on multinational insolvency.) 
In our view, the widespread dissatisfaction with bankruptcy laws around the world stems largely from the fact that structured bargaining fails to separate the issues of efficiency and distribution. The coupling of these issues serves to complicate the bargaining process quite considerably -of ten leading to delay and wastage, and to a final plan that fails to put assets to their most productive use. For example, senior creditors may press for a plan which releases money quickly (since their debt will then be paid for sure); whereas junior creditors may argue for delay (since they enjoy upside changes in the firm's value, but not the downside risk). It is a recipe for failure to mix the decision over which cake to choose (which plan to adopt) with the decision over how the cake should be divided (whose debt should be forgiven, and by how much).

When structured bargaining fails, liquidation is the usual fall-back procedure: the firm's assets are automatically sold/auctioned for cash (e.g. Chapter 7 in the U.S.). Liquidation has clear virtues: there is no ambiguity in the ranking of cash offers; distribution is not an issue (the cash receipts are simply distributed among claimants according to the priority of their claims); and if the auction works perfectly, selling the firm to its highest bidder leads to an efficient outcome. However, when capital markets are imperfect, the best managers may not be able to raise the cash necessary to buy the firm. The firm may be inefficiently dismantled, and its assets sold off cheaply at fire-sale prices. That is, in a cash auction, not only might the final deployment of assets be inefficient, but also the firm's claimants may receive less than they should.

There are further problems with bankruptcy law in some countries. Court procedures are impaired by inefficient judicial systems or corruption (Keefer and Knack, 1993). Laws can be underdeveloped and vague (see, for example, Price Waterhouse, 1995, on Russian bankruptcy law). Title to property is of ten difficult to ascertain because of poor registration systems (Fleisig, Simpson and Rover, 1995). Deficient accounting standards make it harder to sort out the claims and determine if bond covenants have been breached (Center for International Financial Analysis and Research, 1994). 
The practical consequence of these deficiencies is that creditors are usually unable to recoup more than a small fraction of their claims, at the end of a long procedure lasting years or even decades, during which the value of the firm's assets is dissipated (Lipkin, 1995; La Porta, Lopez-de-Silanes, Shleifer and Vishny, 1996a).

Given the high costs of court-sanctioned reorganizations, firms often attempt to solve their financial problems informally. But when there are many creditors, the parties find it difficult to reach agreement (Gilson, John and Lang, 1990; John, 1993). Even when out-of-court settlements can be agreed, the bargaining position of creditors is compromised by the lack of an effective collective procedure.

Entrepreneurs resort to putting up their personal property as collateral, because it is not subject to the provisions of commercial bankruptcy law. Unfortunately, personal property can back only so much debt.

Arguably the most important cost of bad bankruptcy law is an ex ante cost: firms are less able to finance profitable projects. We think that a significant benefit of adopting our procedure may be to lower the cost of external borrowing, and thereby encourage the growth of investment (La Porta, Lopez-de-Silanes, Shleifer and Vishny, 1996b).

\section{A new bankruptcy procedure}

There are three principal steps to our procedure (the timescale is only approximate):

\section{STEP 1 (months 1-3)}

Once formal bankruptcy is triggered (either by the debtor or by unpaid creditors), the court places an automatic stay on creditors' rights to seize the firm's assets, and appoints a receiver, who has two immediate tasks, to be performed concurrently: 
Task A: Draw up a list of the claims against the firm, and decide on their priority.

This list may well not be definitive, since there are likely to be contentious claims. However, this need not hold up the bankruptcy: the procedure can go ahead on the basis of a provisional list of claimants, and an appropriate settlement can take place ex post.

Task B: Solicit reorganization offers in cash and/or non-cash securities for the whole firm or its parts.

The point of allowing non-cash offers is to side-step capital market imperfections which prevent potential bidders from raising cash. As an example of a non-cash offer, the old management team may propose to continue running the business, offering claimants equity in the post-bankruptcy firm. Or the same financial arrangement may be offered by an outside management team. Or management (old or new) may offer claimants a combination of shares and bonds in the post-bankruptcy firm.

We envisage that tasks $A$ and $B$ may take around three months. During this period, someone needs to run the firm's day-to-day operations; this could either be the receiver, or the old managers under the receiver's supervision.

At the end of the three months, the receiver announces the list of the firm's claimants (creditors and shareholders), and makes public all reorganization offers received for the firm.

\section{STEP 2 (month 4)}

The receiver then issues one hundred Reorganization Rights (RRs), each representing a $1 \%$ stake in the firm and conferring the right to a vote at the meeting of RR-holders that will be convened later to decide on the future of the firm (step 3 below). RRs are allocated by means an inside auction followed by a public auction. We postpone giving full details of these auctions until sections 5 and 6 . Briefly, in the inside auction: 
The most senior creditors are initially allocated all 100

RRs, pro-rata; i.e. according to the size of each creditor's debt. However, the RRs can be called (redeemed) by the receiver for an amount which pays off this debt. In addition, each junior claimant is given, pro-rata, options to acquire RRs at a unit price equal to $1 \%$ of the claims that have higher priority; but, again, the RRs can be called for an amount which pays of his claim (taking into account what he paid to acquire them).

The purpose here is to give claimants an opportunity to buy RRs on preferential terms, before the public auction opens. (We discuss this matter in Section 4.) Briefly, in the public auction:

Outside investors are invited to submit cash bids to buy RRs from those claimants who acquired RRs in the inside auction. A claimant is obliged to relinquish his RRs if and only if his claim can be paid in full from the revenue raised from the outsiders' bids (taking into account what he paid to acquire his RRs in the inside auction).

The purpose of the public auction is twofold. First, it provides an early opportunity for at least some creditors to sell their RRs for cash. This goes some way towards respecting ex ante debt contracts, which stipulate that creditors are to be paid in cash, not in RRs. Second, it generates surplus revenues which can be used to compensate any liquidity-constrained claimants who were unable to exercise their options to acquire RRs in the inside auction.

We envisage that the inside and public auctions may be completed within a month.

Once these auctions are completed, all outstanding claims against the firm -- the old shares and debt claims -- are cancelled: the only securities remaining are the $100 \mathrm{RRs}$. In effect, the firm becomes a new, "all-RR" firm. And the new RR-holders may be a mix of former claimants and outside investors; from now on there is no distinction. 
Finally, the new holders of RRs meet to vote and select the best reorganization offer solicited by the receiver (task $B$ ). The firm emerges from bankruptcy.

We must stress that it is not part of our thinking that all firms should survive the procedure intact. The winning reorganization offer may be a plan to wind up the firm and dispose of its assets, or it may be a cash offer from a specialist liquidator.

The over-arching idea behind the procedure is that at the time of the vote, the offers solicited for the firm are likely to be quite complex and heterogeneous -- coming from different management teams, and comprising different mixtures of cash and non-cash securities -- and therefore cannot be evaluated objectively. But the electorate is homogeneous: the group of former creditors and shareholders has been transformed into a (possibly different) group of RR-holders, whose common aim is to maximize the value of the firm. That is, the people who finally assess the offers and decide on the firm's future are the people whose money is on the line at this point; and their interests are aligned. It is the transformation of claims, achieved by means of the inside and public auctions, which sharply distinguishes our proposal from existing structured bargaining procedures.

4. Why have an inside auction and a public auction?

Note that the above procedure differs from that proposed in Aghion, Hart and Moore (1992, 1995) in one key respect. The important new feature is the public auction for RRs.

Readers may wonder why the public auction does not make the inside auction superfluous. In other words, instead of outside investors buying RRs from those claimants who acquired RRs in the inside auction, everyone could simply make cash bids to buy RRs directly from the receiver in a public 
auction -- with the revenues distributed among claimants according to the priority of their claims, just as in a liquidation procedure.

The inside auction would indeed be unnecessary if outsiders always bid the true value of the RRs. (In passing, we should observe that if capital markets work perfectly our procedure achieves the same outcome as a straight liquidation.) But if a public auction does not work well (capital markets are imperfect), outsiders might have the cash to outbid the firm's claimants, and yet get away with bidding less than the true value of the RRs. The purpose of the inside auction is to give claimants an opportunity to acquire RRs on preferential terms, relative to outsiders in the public auction.

To understand this, take an example of a firm which owes $\$ 100$ of senior debt, but the best reorganization offer is perceived to be worth $\$ 90$ (i.e. RRs are worth $\$ 0.9)$. Suppose that, because of capital market imperfections, bids in a public auction are only $\$ 0.6$ per RR (i.e. two thirds of the true value). Consider an individual senior creditor who is owed $\$ 1$, and who has no cash. Since junior claimants won't exercise their options in the inside auction (the option price is greater than the value of an $R R$ ), the senior creditor acquires an RR automatically. Thanks to the inside auction, he has $1 \%$ of the firm, worth $\$ 0.9$. Contrast this with the case where no inside auction is held. Then the senior creditor would never acquire an RR, since, by assumption, he has no cash with which to bid in a public auction. All that he would get is his fraction of the revenue generated -- namely $\$ 0.6$. In sum, because the inside auction gives the senior creditor an opportunity to acquire an $\mathrm{RR}$ on preferential terms, our procedure respects his legitimate right to $1 \%$ of the firm.

Much the same logic applies to junior claimants. For example, consider a shareholder in a firm which is perceived to be worth more than its total debt. (To rationalize this, suppose that although the firm may have been bankrupt under its old managers, the receiver has solicited a strong reorganization offer from a new management team, which is anticipated to win in the final vote.) The inside auction allows a $1 \%$ shareholder to buy an $R R$ simply by bidding $1 \%$ of the firm's debt, rather than by having to match bids placed by outsiders in the public auction. We think that this is an important principle: former owners should have the right to keep a stake in 
the post-bankruptcy firm if they are willing and able to buy out their slice of the firm's debt; they should not have to compete against outsiders.

These ideas should be clearer once we have laid out the rules of the inside and public auctions, and looked at some more examples.

\section{Details of the inside auction}

Suppose that during the first three months of the bankruptcy procedure, the receiver identifies the following claims against the firm (task $A$ ): there are $n$ classes of creditors who are owed (in total) the amounts $D_{1}, \ldots, D_{n}$, respectively -- with class 1 having the most senior claim, class 2 the next most senior, and so on. The firm's shareholders form the $(n+1)^{\text {th }}$ class, with a claim junior to all others.

Once the three months are up, the receiver makes known all the reorganization offers that he has solicited for the firm (task B). Claimants are then given time to analyze these offers (possibly with the help of specialist advice), and decide how they are going to act in the inside auction.

Initially, the receiver issues all $100 \mathrm{RRs}$ to the most senior creditors (class 1); however he has the right to call RRs held by class 1 creditors at a unit price of $D_{1} / 100$. A creditor in the next most senior class (class 2) who is owed $d_{2}$, say, is given the option to buy up to his pro-rata number, $100\left(\mathrm{~d}_{2} / \mathrm{D}_{2}\right)$, of RRs at a unit price $\mathrm{p}_{2}$ equal to $\mathrm{D}_{1} / 100$; however the receiver has the right to call RRs held by class 2 creditors at a unit price of $\left(D_{1}+D_{2}\right) / 100$. Similarly, for $i=3, \ldots, n$, a creditor in class $i$ who is owed $d_{i}$ is given the option to buy up to $100\left(d_{i} / D_{i}\right)$ RRs at a unit price $p_{i}$ equal to $\left(D_{1}+D_{2}+\ldots+D_{i-1}\right) / 100$; however the receiver has the right to call RRs held by class $i$ creditors at a unit price of $\left(D_{1}+D_{2}+\ldots+D_{i}\right) / 100$. Finally, a shareholder who holds $z \%$ of the equity of the firm is given the option to buy up to $z$ non-callable $R R$ at a unit price $p_{n+1}$ equal to $\left(D_{1}+D_{2}+\ldots+D_{n}\right) / 100$.

The inside auction may take several rounds. In round 1 , the shareholders (class $n+1$ ) are allowed to exercise their options to buy RRs at 
price $p_{n+1}$. If they exercise all of their options, the proceeds are just enough to pay all the firm's debt, and the auction ends. If they exercise none of their options, the auction moves to round 2 (see below). If they exercise some of their options -- e.g. suppose they exercise the right to buy $q_{n+1}$ RRs, where $0<q_{n+1}<100--$ then the funds generated, $q_{n+1} p_{n+1}=C_{n+1}$ (say), are handed to class $n$ claimants in return for an obligation to supply $q_{n+1}$ RRs to the shareholders. The class $n$ claimants are compelled to use the cash $C_{n+1}$ to exercise their options to buy RRs at price $p_{n}$. On the one hand, if $C_{n+1} \geq 100 p_{n}$, then all claimants senior to class $n$ (i.e. classes $1,2, \ldots, n-1)$ are fully paid; class $n$ receives $100-q_{n+1}$ RRs, plus $C_{n+1}-100 p_{n}$ in cash; class $n+1$ (the shareholders) receives $q_{n+1} R R s$, having paid out $C_{n+1}$ in cash; and the auction ends. On the other hand, if $C_{n+1}<100 p_{n}$, then the cash $C_{n+1}$ is handed to class $n-1$ claimants in return for an obligation to supply $q_{n}=C_{n+1} / p_{n}$ RRs to class $n$. In this case, class $n$ receives, net, $q_{n}-q_{n+1}$ RRs (but no cash); and the class $n-1$ claimants are compelled to use the cash $C_{n+1}$ to exercise their options to buy RRs at price $p_{n-1}$. And so on, until either a point is reached where everyone senior to some class $i \geq 2$ has been fully paid, or all the cash $C_{n+1}$ is in the hands of class 1 .

In round 2, members of class $n$ are allowed to exercise any remaining options to buy RRs at price $p_{n}$. And so on. The auction ends after round $j$, where $j$ is such that everyone senior to class $n-j+1$ has been fully paid. (It is possible that $j=n$, which means that no class is fully paid.)

A crucial feature of the auction is that, when exercising his options, an individual class $i$ creditor who is owed $d_{i}$ has to find only enough cash to pay his pro-rata share of the debt senior to him. That is, he has to find only $\left(d_{i} / D_{i}\right)\left(D_{1}+\ldots+D_{i-1}\right)$ dollars. The procedure is thus decentralized: there is no need for the creditors to coordinate their actions.

The rules of the inside auction are adapted from the scheme developed by Bebchuk (1988) for swapping debt for equity in a bankrupt firm. (The differences only arise if some but not all members of a class decide to exercise their options.) Bebchuk's scheme has the unpalatable feature that junior claimants may receive cash even when senior creditors have not been fully paid. Our inside auction procedure avoids this, thanks to a cascading 
effect: cash moves up the hierarchy from junior to senior claimants, and RRs move down the hierarchy.

To see how the inside auction works in a simple example, consider the following example.

Example 1 A firm has three classes of creditors, and each class is owed $\$ 100$ (i.e. $\mathrm{n}=3$ and $\mathrm{D}_{1}=\mathrm{D}_{2}=\mathrm{D}_{3}=\$ 100$ ). Also assume that the best reorganization offer for the firm is perceived by everyone to be worth $\$ 250$; i.e. an RR is perceived to be worth $\$ 2.5$. Finally, assume that no-one is liquidity constrained. (We relax this assumption in Example 2 below.)

Initially, the receiver issues all 100 RRs to the class 1 creditors, pro-rata; but he has the right to call RRs held by class 1 creditors at a unit price of $\$ 1$. Class 2 creditors are given, pro-rata, options to buy RRs at a price $\mathrm{p}_{2}=\$ 1$; but RRs held by class 2 creditors can be called at a unit price of $\$ 2$. Class 3 creditors are given, pro-rata, options to buy RRs at a price $\mathrm{p}_{3}=\$ 2$; but RRs held by class 3 creditors can be called at a unit price of $\$ 3$. The shareholders are given, pro-rata, options to buy non-callable RRs at a price $\mathrm{p}_{4}=\$ 3$.

In round 1 of the inside auction, the shareholders do not exercise their options, since the value of an RR, $\$ 2.5$, is less than their option price $\mathrm{p}_{4}=\$ 3$. In round 2 , the class 3 creditors exercise all their options, since the value of an $R R$ is more than their option price $p_{3}=\$ 2$. The funds generated, $\$ 200$, are just enough to pay all the class 1 and class 2 debt, and the auction ends. A class 3 creditor who was owed $\$ 1$ receives one RR worth $\$ 2.5$, having paid out $\$ 2$. Shareholders receive nothing.

To see how the inside auction works in a richer example, see Example 2 in Section 6.

Notice that Example 1 works out so satisfactorily only because each of the class 3 creditors is able to come up with enough cash to exercise his options. In Example 2, some of these creditors are liquidity constrained. 
The receiver now invites outside investors to place cash bids for RRs. (If they want, claimants may place bids too.) From the bids he receives, the receiver constructs a demand schedule. See Figure 1 by way of illustration.

At the start of the public auction, all $100 \mathrm{RRs}$ are in the hands of those claimants who succeeded in acquiring RRs in the inside auction. These people are effectively the suppliers in the public auction. To protect their interests in the event of weak outside demand, reserve prices are set at levels such that if some claimant's RRs are repurchased from him in the public auction then he receives just enough to pay off his claim (taking into account what he paid to acquire the RRs in the inside auction). In effect, a supply schedule is constructed by ranking the RRs according to their call price -- where the call price of an RR held by a class $i$ claimant equals $p_{i+1}$, for $1 \leq i \leq n$.

(At this point, one might choose to put an extra feature into the rules of the public auction: viz., if an individual supplier wants, he can elect to lower the reserve price on his RRs (because he is less bullish about the firm's prospects than outsiders are, or because he needs cash). But no creditor can hold on to his RRs by raising the reserve price. If outside demand is strong enough to pay all that the firm owes him, then he is forced to relinquish his stake in the firm. The exception to this is a shareholder, who, prior to the bankruptcy, was a residual claimant: an RR held by a shareholder is non-callable -- unless, that is, he has elected to lower the reserve price, down from infinity. For ease of exposition, in what follows we shall not include the feature that suppliers can elect to lower their reserve prices.)

Figure 1 illustrates a possible supply schedule for $\mathrm{n}=3$, where, unlike in Example 1, some of the class 3 creditors did not exercise their options in the inside auction (e.g. because of liquidity constraints). Here, $q_{1}$ of the RRs are held by class 1 creditors and have a call price of $p_{2} ; q_{2}$ of the RRs are held by class 2 creditors and have a call price of $p_{3}$; the remainder of the RRs, $100-q_{1}-q_{2}$, are held by class 3 creditors and have a call price of $\mathrm{p}_{4}$. No RRs are held by shareholders. 


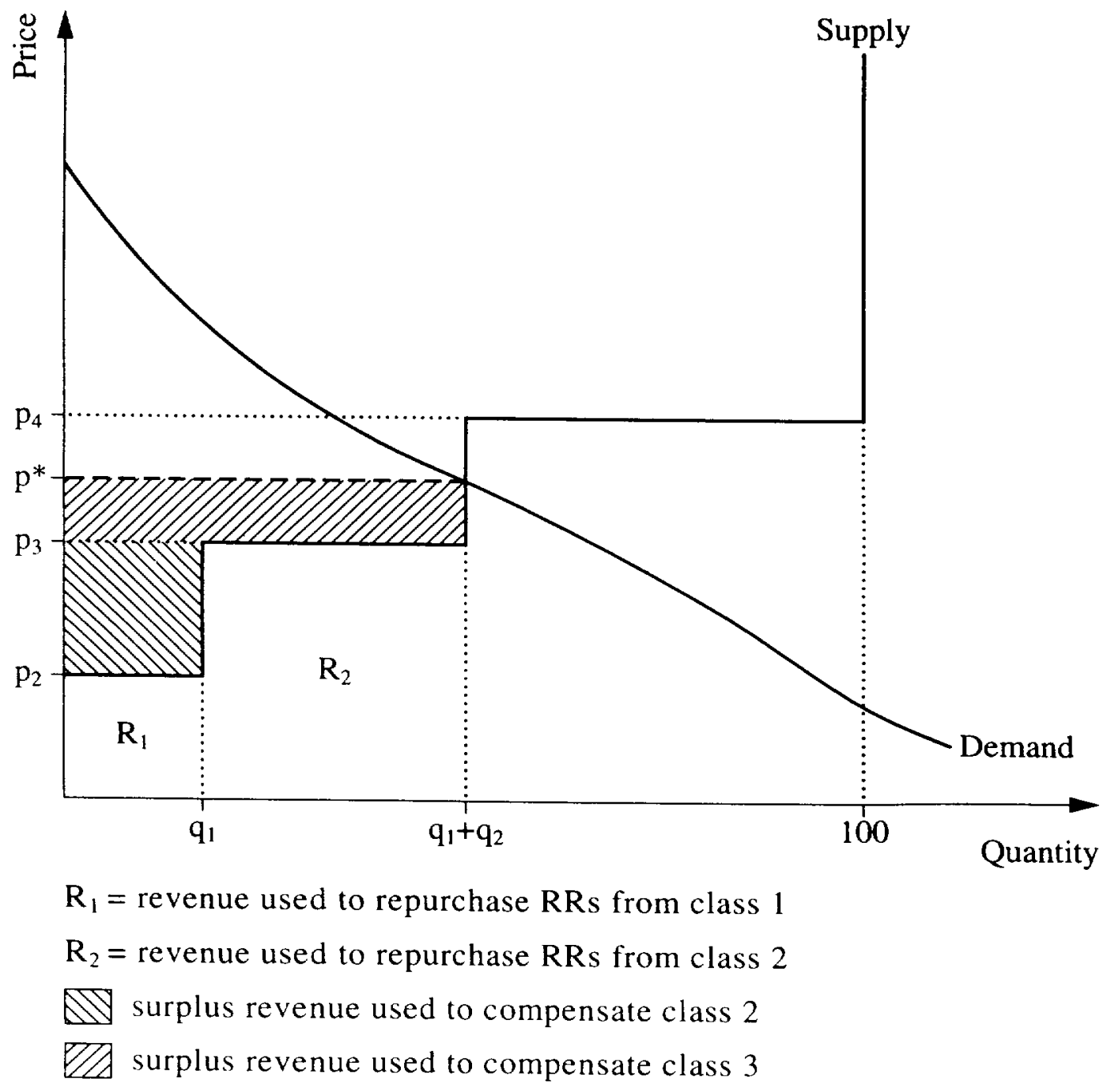

Fig. 1. 
The receiver calculates the equilibrium price, $\mathrm{p}^{*}$ say, at which the supply and demand schedules intersect. In Figure 1, it turns out that $p^{*}$ lies strictly between $p_{3}$ and $p_{4}$, and the equilibrium quantity is $q_{1}+q_{2}$. The outsiders who bid more than $p^{*}$ end up paying in total $\left(q_{1}+q_{2}\right) p^{*}$ for $q_{1}+q_{2}$ RRs; the rest pay nothing and get nothing. (In other words, we propose using a non-discriminating auction. It would be quite possible to price discriminate, but note that this would change the outsiders' bidding strategies.) The suppliers of the $q_{1}+q_{2}$ RRs are paid their respective call prices; and so, by construction, their claims against the firm are met in full. Specifically, the $q_{1}$ RRs held by class 1 creditors are repurchased for $p_{2}$-- using up $q_{1} p_{2}=R_{1}$ of the total revenue $\left(q_{1}+q_{2}\right) p^{*}$ in Figure 1 . And the $q_{2}$ RRs held by class 2 creditors are repurchased for $p_{3}$-- using up $q_{2} p_{3}=R_{2}$. The surplus revenue, $\left(q_{1}+q_{2}\right) p^{*}-R_{1}-R_{2}$, generated by the difference between $p^{*}$ and the call prices paid to suppliers (the sum of the shaded areas in Figure 1 ), is used by the receiver to compensate impaired claimants in accordance with their seniority. In terms of Figure 1, one can show that, because $p^{*}>p_{3}$, this surplus revenue is more than enough to pay off the class 2 debt; but, because $p^{*}<p_{4}$, there isn't enough revenue to meet in full the claims of the "non-participating" class 3 creditors, i.e. those who did not acquire RRs in the inside auction. (See the two differently shaded areas in Figure 1.) Shareholders receive nothing.

To see how the public auction works, consider the following example.

Example 2 Everything as in Example 1, except that now suppose class 3 comprises 100 creditors, each of whom is owed $\$ 1$, but 60 of whom are liquidity constrained and so are unable to exercise their options. (None of the other claimants is liquidity constrained.) Also assume that the outside demand for RRs is perfectly elastic at $\$ 2.5-$ - i.e. outside investors bid the true value of the firm.

As in Example 1, nothing happens in round 1 of the inside auction: the shareholders do not exercise their options since the value of an $R R, \$ 2.5$, is less than their option price $p_{4}=\$ 3$. In round 2 , the 40 class 3 creditors 
who are not liquidity constrained exercise their options to buy RRs at price $p_{3}=\$ 2$. The funds generated, $\$ 80$, are handed to the class 2 creditors in return for an obligation to supply $40 \mathrm{RRs}$ to class 3 . The class 2 creditors are compelled to use the $\$ 80$ to exercise their options to buy RRs at price $p_{2}=\$ 1$. Since $\$ 80$ is not enough to exercise all 100 of these options, the cash is handed to class 1 creditors in return for an obligation to supply 80 RRs to class 2. By the end of round 2, then, class 1 creditors hold 20 RRs; class 2 creditors hold $80-40=40$ RRs; and the 40 unconstrained creditors in class 3 hold 40 RRs. (No RRs are held by the liquidity constrained class 3 creditors, or by the shareholders.) Additionally, the 40 unconstrained creditors in class 3 have in effect given $\$ 80$ in cash to the class 1 creditors.

In round 3, the class 2 creditors exercise their remaining 20 options to buy RRs at price $p_{2}=\$ 1$. They pay $\$ 20$ in cash to class 1 in exchange for 20 RRs. Class 1 is fully paid, and the inside auction ends.

Hence, at the start of the public auction, $40+20=60$ RRs are held by class 2 creditors, callable at price $p_{3}=\$ 2$; and 40 RRs are held by class 3 creditors, callable at price $p_{4}=\$ 3$. This means that the supply schedule is horizontal at $\$ 2$ for quantities less than 60 ; horizontal at $\$ 3$ for quantities between 60 and 100; and becomes vertical at 100 .

Since, by assumption, the demand schedule is perfectly elastic at $\$ 2.5$, the equilibrium price $p^{*}$ equals $\$ 2.5$, and the equilibrium quantity equals 60 . Outside bidders pay $\$ 2.5$ for each of $60 \mathrm{RRs}$. To meet this demand, the receiver calls the 60 RRs held by class 2 claimants, each at a price of $\$ 2$. Class 2 is fully paid. The surplus revenue of $60 \times(\$ 2.5-\$ 2)=\$ 30$ is used to compensate the 60 class 3 creditors who did not participate in the inside auction; i.e. they each receive $\$ 0.5$.

Now compare the situations of the two types of class 3 creditor: liquidity constrained and unconstrained. By the end of the inside and public auctions, a liquidity constrained class 3 creditor has received $\$ 0.5$ in cash. An unconstrained class 3 creditor has received one RR worth $\$ 2.5$, having paid out $\$ 2$ (incidentally, this is exactly what class 3 creditors received in Example 1, where they were all unconstrained). That is, the two types fare 
equally well. The public auction has succeeded in fully compensating the liquidity constrained members of class 3 . Without the public auction, these people would have received nothing.

\section{Further considerations}

In this short paper, there has only been space to describe the main aspects of our model. A host of other matters deserve proper consideration. For example: the ex-post resolution of claims disputes; the treatment of secured creditors and special creditors (workers, the state); managing the business during bankruptcy; emergency asset sales; interim financing; assembling coherent plans from partial offers for the firm; the appointment of disinterested specialists to advise claimants; voting procedures; the protection of minority RR-holders. There are other questions too. Might some version of our procedure help informal workouts to succeed? Should our procedure be compulsory? We have written about these matters elsewhere: see Aghion, Hart and Moore (1992, 1994, 1995); Hart, La Porta Drago, Lopez-de-Silanes, Moore and Salas (1995); and Chapter 7 of Hart (1995) -although these writings predate the bankruptcy procedure contained in the present paper. 


\section{References}

Aghion, P., O. Hart and J. Moore, 1992, The Economics of Bankruptcy Reform, Journal of Law, Economics and Organization 8, 523-46.

Aghion, P., O. Hart and J. Moore, 1994, Improving Bankrupcty Procedure, Washington University Law Quarterly 72, 811-27.

Aghion, P., O. Hart and J. Moore, 1995, Insolvency Reform in the UK: A Revised Proposal, Insolvency Law and Practice 11, 67-74.

American Bar Association, 1989 and 1993, Multinational Commercial Insolvency (MG Publishing, Wisconsin).

Bebchuck, L., 1988, A New Approach to Corporate Reorganizations, Harvard Law Review 101, 775-804.

Center for International Financial Analysis and Research Inc., 1994, International Accounting and Auditing Trends.

Fleisig, H., J. Simpson and J.-H. Rover, 1995, Security Interests in Moveable Property in Transition Economies: Issues and Options for Reform, Background Paper for The World Development Report 1996: From Plan to Market, The World Bank, Washington D.C.

Gilson, S., K. John and L. Lang, 1990, Troubled Debt Restructurings: An Empirical Study of Private Reorganization of Firms in Default, Journal of Financial Economics 26, 315-53.

Hart, O., 1995, Firms, Contracts and Financial Structure (Clarendon Press, Oxford, U.K.)

Hart, O., R. La Porta Drago, F. Lopez-de-Silanes, J. Moore and F. Salas, 1995, Proposal for a New Bankruptcy Procedure in Mexico, mimeo, Harvard University. 
John, K., 1993, Managing Financial Distress and Valuing Distressed

Securities: A Survey and Research Agenda, Financial Management 2, 60-78.

Keefer, P. and S. Knack, 1993, Why Don't Poor Countries Catch Up? A Cross Country National Test of an Institutional Explanation, Center for Institutional Reform and the Informal Sector, University of Maryland at College Park, Working Paper No. 60.

La Porta Drago, R., F. Lopez-de-Silanes, A. Shleifer and R. Vishny, 1996a, Law and Finance, National Bureau of Economic Research, Working Paper No. 5661 .

La Porta Drago, R., F. Lopez-de-Silanes, A. Shleifer and R. Vishny, 1996b, Investor Rights and External Financing Around the World, mimeo, Harvard University.

Lipkin, A., 1995, Legal Framework for Bankruptcy and Reorganization Proceedings in Emerging Markets, The 1995 Bankruptcy Yearbook and Almanac (George Putnam III publisher, New Generation Research Inc., Boston, Massachusetts).

Price Waterhouse, 1995, Bankruptcy Law in the Russian Federation, Report to the Russian Federation, Moscow. 